\title{
Covid-19: How Industrial Animal Agriculture Fuels Pandemics
}

Why People and Animals are in it Together: A One-Health perspective on people, animal production and a safer environment.

\author{
Philip Lymbery \\ Global Chief Executive, Compassion in World Farming \\ Visiting Professor, University of Winchester, UK
}

Received: August 2020

Accepted: December 2020

Cita recomendada LYMBERY, P., Covid-19: How Industrial Animal Agriculture Fuels Pandemics, dA. Derecho Animal (Forum of Animal Law Studies) 11/4 (2020). - DOI https://doi.org/10.5565/rev/da.514

\begin{abstract}
The battle against the Coronavirus pandemic is without doubt the biggest global crisis in a lifetime. Could it be that the way we now produce so much of our food worldwide is already brewing up the next one? Whilst society has gone into battle with the virus, our invisible enemy, the truth is we've been locked in an almighty battle for some time now. At its heart lies factory farming. Keeping animals caged, crammed and confined - the way most farmed animals are now reared - provides the ideal breeding ground for new and more deadly strains of virus. Swine flu and highly pathogenic Avian flu being but two examples. Whilst Covid-19 is believed to be born out of the ill-treatment of animals caught up in wet markets and the illegal wildlife trade, it shows strong parallels with these other viruses of factory farmed origin. Both Swine flu and Avian Influenza - originating in pigs and chickens - have been devastating. The 2009 Swine flu pandemic went on to kill possibly half a million people worldwide. The next pandemic could well come from an incarcerated pig or chicken. From animals 'grown' like mere commodities and fed on the fruits of deforestation. Without ending the intensive farming conditions that promote the emergence of novel strains of viral disease, the next pandemic could well be on our plate.
\end{abstract}

Key words: pandemic; global crisis; food; virus; factory farming; animals; Swine flu; Avian flu; Covid-19.

\section{Resumen - Covid-19: Cómo la ganadería industrial propicia pandemias}

La batalla contra la pandemia de Coronavirus es sin lugar a dudas la mayor crisis global en toda la vida. ¿Podría ser que la forma en la que ahora producimos gran parte de nuestros alimentos alrededor del mundo está ya preparando la siguiente? Si bien la sociedad ha entrado en batalla con el virus, nuestro enemigo invisible, la verdad es que hemos estado atrapados en una batalla todopoderosa desde hace algún tiempo. En su corazón se encuentra la ganadería industrial. Mantener a los animales enjaulados, hacinados y confinados - como se crían hoy en día la mayoría de los animales de granja - proporciona el caldo de cultivo ideal para cepas de virus nuevas y más mortales. La gripe porcina y la altamente patógena gripe aviar son solo dos ejemplos. Si bien se cree que el Covid-19 nace del maltrato de animales enjaulados en mercados húmedos y el comercio ilegal de vida silvestre, muestra fuertes paralelismos con estos otros virus que tienen su origen en la ganadería industrial. Tanto la gripe porcina como la gripe aviar - que se originan en los cerdos y las gallinas - han sido devastadoras. La pandemia de gripe porcina de 2009 terminó probablemente con la vida de medio millón de personas en todo el mundo. La próxima pandemia bien podría provenir de un cerdo o pollo encarcelado. De animales "cultivados" como meros productos básicos y alimentados con los frutos de la deforestación. Sin poner fin a las condiciones de cultivo intensivo que promueven la aparición de nuevas cepas de enfermedades virales, la próxima pandemia bien podría estar en nuestro plato. 
Palabras clave: pandemia; crisis global; comida; virus; ganadería industrial; animales; gripe porcina; gripe aviar; Covid-19.

Covid-19 has turned billions of lives upside down and caused us all to question whether things will ever be the same. This paper seeks to highlight the known pandemic risks inherent in contemporary industrial methods of animal production, and how we can minimise those risks in future.

Unimaginable is the word most of us might have used to describe a distant virus originating in bats and traced to a live animal market in Wuhan, China, becoming so world changing. To their credit, Chinese authorities moved quickly once Coronavirus had been identified, to shut down both the affected market and the illegal trade in wildlife, at least temporarily. Nearly 20,000 wildlife farms across China raising species including peacocks, civet cats, porcupines, ostriches, wild geese and boar were also shut down.

The world was caught seemingly unawares. Yet, in truth, the warning signs have been there for two decades; and have a lot to say about the future of food, farming and our relationship with animals. In 2003 a Lancet article asked 'Will the virus re-emerge from wet markets or from laboratories working with SARS $\mathrm{CoV}$, or are asymptomatic infections ongoing in human beings? Similar questions can be asked about a pandemic of influenza that is probably imminent'. ${ }^{1}$

\section{Pandemic on a Plate}

Although bats are thought to be the original source, the Wuhan coronavirus most likely jumped to humans via an intermediary, possibly a scaly mammal akin to anteaters and armadillos called a pangolin. ${ }^{2}$ It is the latest example of the many pathogens that have made the leap from animals into humans. Three out of four new or emerging infectious diseases in people come from animals, including HIV, Ebola, influenza, MERS and SARS. ${ }^{3}$

Whilst the emergence of Covid-19 has been linked to the consumption of wildlife, it shows strong parallels with other viruses which have emerged from a different route - industrial farming - such as highly pathogenic strains of Avian Influenza and Swine Flu.

Both these diseases - originating in chickens ${ }^{4}$ and pigs ${ }^{5}$ - have been devastating to human societies and are known to have arisen from keeping living, breathing, sentient creatures in the most unnatural conditions - caged, crammed and confined on intensive farms.

Intensive farm buildings are a serious public health risk. ${ }^{6}$ In spite of claims of enhanced biosecurity, they provide the perfect breeding ground for disease. Keeping too many animals in too small a space, often in filthy conditions, provides a virus such as Avian Influenza the environment it needs to thrive and spread rapidly. ${ }^{78}$ As it replicates within the thousands of hosts provided by an intensively managed flock of chickens, mutations can occur in the viral DNA, causing new and more deadly strains to emerge. ${ }^{9}$

Highly pathogenic bird flu strains, such as the H5N1 virus, emerged during a time of massive expansion of the poultry industry in the Far East. Spreading rapidly, by August 2011, it had infected 564 people, of

\footnotetext{
${ }^{1}$ WEBSTER, R.G., Wet markets - a continuing source of severe acute respiratory syndrome and influenza? Lancet, 363 (2004) $234-$ 36

2 WALZER, C., COVID-19 and the Curse of Piecemeal Perspectives. Front. Vet. Sci. 7 (2020) 582983. https://www.frontiersin.org/articles/10.3389/fvets.2020.582983/full

3 Centers for Disease Control and Prevention, Zoonotic Diseases, [online] https://www.cdc.gov/onehealth/basics/zoonoticdiseases.html

${ }^{4}$ GREGER, M., The Human/Animal Interface: Emergence and Resurgence of Zoonotic Infectious Diseases, Critical Reviews in Microbiology, 33 (2007) 243-299

${ }^{5}$ GIBBS, J.A., ARMSTRONG, J.S., DOWNIE, J.C., From where did the 2009 'swine-origin' influenza A virus (H1N1) emerge? Virology Journal, 6 (2009) 207 http://www.virologyj.com/content/6/1/207

6 OTTE, J. et al. Industrial Livestock Production and Global Health Risks. Pro-Poor Livestock Initiative (June 2007) www.fao.org/ag/AGAinfo/projects/en/pplpi/docarc/rep-hpai_industrialisationrisks.pdf

7 American Public Health Association APHA Precautionary Moratorium on New and Expanding Concentrated Animal Feeding Operations (Nov 05 2019), Policy Number: 20194, https://www.apha.org/policies-and-advocacy/public-health-policystatements/policy-database/2020/01/13/precautionary-moratorium-on-new-and-expanding-concentrated-animal-feeding-operations

${ }^{8}$ Avian influenza goes global, but don't blame the birds. Leading Edge (editorial). The Lancet Infectious Diseases, 6 (April 2006) 185, https://www.thelancet.com/journals/laninf/article/PIIS1473-3099(06)70417-0/fulltext

${ }^{9}$ DHINGRA, M.S. et al., Geographical and Historical Patterns in the Emergences of Novel Highly Pathogenic Avian Influenza (HPAI) H5 and H7 Viruses in Poultry, Frontiers in Veterinary Science, 5 (2018) 84, doi: 10.3389/fvets.2018.00084
} 
whom 330 died - a fatality rate of almost 59 per cent. ${ }^{10}$

Thankfully, H5N1 is not easily transmitted between people. However, scientists have shown that just a few mutations would allow H5N1 to become as infectious as seasonal flu. ${ }^{11}$ An editorial in the New Scientist described the risk of a pandemic as 'fact, not fiction'. ${ }^{12}$

The fact that pigs, humans and birds can exchange flu viruses or elements of viruses, ${ }^{13}$ undeniably raises the nightmare prospect of a highly contagious and lethal flu strain which starts in animals and transfers to people.

To an extent, it already has: with Swine flu. ${ }^{14}$

I remember visiting the mountain plateau town of La Gloria in south-east Mexico, known as 'ground zero' for Swine flu. I remember the eerie sense of gloom on the streets, once a cheerful place where children played volleyball on dusty roads and in streets decorated with bunting. Those streets lay just five miles from one of the biggest concentrations of pig farms in the world. I remember driving past more than a dozen pig farms scattered across the desert plain outside the town. More than a million pigs a year are raised in the area. I spent several days there and didn't see a single pig. They were all locked inside. Out of sight. Reared in cramped, concrete pens, their muck flushed into open air lagoons. The smell was overwhelming. The word 'farm' barely seemed to apply here. Each one resembled a cluster of low aircraft hangars or military installations. The steel and concrete electrified boundary fences kept us out. Articulated lorries trundled in and out, ferrying huge quantities of feed. When the finished product - the fattened pigs - were loaded into trucks for slaughter, it might well have been the first time they saw the sun.

In 2009, La Gloria became the epicentre of one of the biggest-ever health crises linked to factory farming.

It spread far more quickly than anyone anticipated: within a week, ten countries were affected; within months, 180 countries had been hit. ${ }^{15}$ The Swine flu pandemic of 2009 went on to kill between 151,700 and 575,400 people worldwide. ${ }^{16}$

When the immediate panic subsided, most people stopped worrying about catching swine flu, just as they stopped worrying about contracting bird flu.

Surely, it would be an unforgivable tragedy if we did the same thing after Covid-19, failing to learn the lessons and act on them.

\section{Black Swan}

New and devastating disease outbreaks have become known as 'black swan' events, a metaphor for surprise catastrophes. ${ }^{17}$ Coronavirus has been a black swan event beyond compare; a real living nightmare.

To avoid nightmares being repeated in the future it is essential to identify likely sources of black swan events.

One of those is factory farming; not only the biggest cause of animal cruelty on the planet, but a major driver of wildlife declines worldwide. ${ }^{18}$ The two are inextricably linked.

At the same time, the volumes and lower retail prices that factory farming makes possible fuel the global appetite for more meat and animal products, with more forests cleared for farmland, encroaching on wild lands and their own viruses.

Food production already covers nearly half the useable land surface of the planet, more than four-fifths

\footnotetext{
${ }^{10}$ World Health Organisation (WHO), Cumulative Number of Confirmed Human Cases of Avian Influenza A/(H5N1) [online] http://www.who.int/csr/disease/avian_influenza/country/cases_table_2011_08_09/en/index.html [Reported to WHO, 9 August 2011]

${ }^{11}$ MACKENZIE, D., Five easy mutations to make bird flu a lethal pandemic, New Scientist (24 September 2011 ) 14 (online article 21 September)

12 Editorial, The risk of an influenza pandemic is fact, not fiction, New Scientist (24 September 2011) 3 https://www.newscientist.com/article/mg21128313-300-the-risk-of-an-influenza-pandemic-is-fact-notfiction/\#: :text=Work\%20reported\%20last $\% 20$ week\%20suggests,flu $\% 20 \mathrm{a} \% 201$ ethal $\% 20$ pandemic\%E2\%80\%9D

${ }^{13}$ Centers for Disease Control and Prevention, Transmission of Avian Influenza A Viruses Between Animals and People, [online] https://www.cdc.gov/flu/avianflu/virus-transmission.htm

${ }_{14}$ GIBBS, J.A., ARMSTRONG, J.S., DOWNIE, J.C., From where did the 2009 'swine-origin' influenza A virus (H1N1) emerge? Virology Journal, 6 (2009) 207 http://www.virologyj.com/content/6/1/207

15 World Health Organisation (WHO), 2009 H1N1 Pandemic $\quad$ (H1N1pdm09 virus) [online] http://www.searo.who.int/linkfiles/news_letters_nov2010.pdf

${ }^{16}$ Centers for Disease Control and Prevention, [online] https://www.cdc.gov/flu/pandemic-resources/2009-h1n1-pandemic.html [Last accessed: April 12, 2020]

${ }^{17}$ Chief Investment Officer, Chinese Virus Could Be a 'Black Swan Like No Other': Moody's (2020) [online] https://www.aicio.com/news/chinese-virus-black-swan-like-no-moodys-says/

${ }^{18}$ LYMBERY, P., Dead Zone: Where the Wild Things Were (London 2017)
} 
of that devoted to producing meat and dairy. ${ }^{19}{ }^{20}$ As the global hunger for animal products increases, so agriculture encroaches further into the world's remaining wildlands. Wilderness areas. Rainforests. Savannah. All rich in wildlife and oxygen-giving woodlands.

As David Quammen, author of Spillover: Animal Infections and the Next Pandemic, wrote in the New York Times, "We invade tropical forests and other wild landscapes, which harbour so many species of animals and plants - and within those creatures, so many unknown viruses. We cut the trees; we kill the animals or cage them and send them to markets. We disrupt ecosystems, and we shake viruses loose from their natural hosts. When that happens, they need a new host. Often, we are it". ${ }^{21}$

A big reason for this encroachment on nature is the rising demand for cheap protein from animals, fuelling agricultural expansion and pushing ever deeper into marginal lands and wild spaces.

Grazing animals, especially cattle, are blamed for the destruction of the rainforest and the march of the agricultural frontier. Yet, what I discovered in Brazil, is that global demand for factory farmed meat is the real driver. The essential feature of contemporary industrial agriculture is that it depends on feed crops such as maize and soy beans.

Longstanding cattle pastures on the savannah plains of Brazil's agricultural interior are being ploughed up for feed crops like soya. ${ }^{22}{ }^{23}$ The demand pushes up land prices, meaning cattle farmers can sell their pasture land to soy farmers and afford to buy more land deeper in the forest. Scientists call this a 'land-use cascade' ${ }^{24}$ In this way it drives rainforest destruction.

Much of the world's arable land is now shared with factory farmed animals.

Growing food - renamed 'feed' - using heavy applications of chemical fertilisers and pesticides. Nearly $40 \%$ of the world's cropland is used to grow animal feed. ${ }^{25} 26$ This is equivalent to more than the area of the EU or half the area of the US. Wiping away nature. Shaking free their viruses in search of new hosts.

Yet, because so much of the world's harvest is squandered by feeding it to factory farmed animals, wasting the majority of the food value in conversion to 'cheap' meat, milk and eggs ${ }^{27} 28$ - we need ever more farmland, and encroach on yet more forests. Which brings us into contact with a new array of wild animals, plants and viruses. Animals most likely to be hosts of human-shared pathogens and parasites are more abundant in human-managed ecosystems. ${ }^{29}$

Whilst loading the dice of sustainability against us for tomorrow, we are literally encroaching on our future. In this way, we put ourselves at risk of a fresh pandemic every day.

\section{Russian Roulette}

The Coronavirus tragedy, together with Avian flu and Swine flu a decade earlier, have shown how treating animals as mere commodities - be they domesticated or wild - is like playing Russian Roulette with peoples' health.

A key component of reducing the risk of devastating diseases tomorrow, is to reconnect with our humanity for animals today. To safeguard the sentience of animals - their ability to feel pain, to suffer, and to experience a sense of joy - whether wild or farmed, lies at the heart of future disease control strategies. One health, one welfare.

The coronavirus epidemic is not a warning but a potent demonstration of what is going wrong and what life could become. Where our global lifestyle seemed invincible, suddenly it seems vulnerable. Fragile.

\footnotetext{
${ }^{19}$ POORE, J., NEMECECK, T., Reducing food's environmental impacts through producers and consumers, Science 360 (2018) $987-$ 992

20 RITCHIE, H., ROSER, M., Our World in Data, Global land use for food production (2019) https://ourworldindata.org/land-use (accessed November 2020)

${ }^{21}$ The New York Times, We Made the Coronavirus Epidemic (2020) [online]

https://www.nytimes.com/2020/01/28/opinion/coronavirus-china.html

${ }^{22}$ RAUSCH, L.L. et al., Soy expansion in Brazil's Cerrado, Conservation Letters, 12 (2019) e12671. https://doi.org/10.1111/conl.12671

${ }^{23}$ FRAANJE, W., GARNETT, T. Soy: food, feed, and land use change. (Foodsource: Building Blocks). Food Climate Research Network, University of Oxford (2020)

${ }^{24}$ ARIMA, E.Y. et al., Statistical confirmation of indirect land use change in the Brazilian Amazon

Environ. Res. Lett. 6 (2011) 024010 [online] https://iopscience.iop.org/article/10.1088/1748-9326/6/2/024010/pdf

${ }^{25}$ MOTTET, A., et al., Livestock: On our plates or eating at our table? A new analysis of the feed/food debate. Global Food Security, 14 (2017) 1-8. Table 2. https://www.sciencedirect.com/science/article/abs/pii/S2211912416300013

${ }^{26}$ Total world cropland area from FAOSTAT: land use in 2018 (FAOSTAT, Inputs: Land use, http://www.fao.org/faostat/en/\#data/RL

${ }^{27}$ CASSIDY, E.M et al., Redefining agricultural yields: from tonnes to people nourished per hectare. University of Minnesota. Environ. Res. Lett. 8 (2013) 034015 doi:10.1088/1748-9326/8/3/034015

${ }^{28}$ BAJŽELJ, B. et al., Importance of food-demand management for climate mitigation, Nature Climate Change, 4 (2014) 924-929

${ }^{29}$ GIBB, R. et al., Zoonotic host diversity increases in human-dominated ecosystems, Nature , 584 (2020) 398-402
} 
Interdependent.

No one could have wanted such a terrible pandemic, claiming so many human lives and devastating countless others. The scale of human tragedy is immeasurable.

Yet, out of this darkest cloud of contemporary history could come a silver lining that may just save us from worst things to come. Living through the unimaginable could provide people and policy makers with the experience to rethink how to tackle problems anew.

\section{EU Calls for Global Action}

Industrial agriculture increases the 'risk of future pandemics and needs to be tackled', is how the EU's ruling Council in Brussels put it in a statement in July 2020 setting out its global priorities at the UN. ${ }^{30}$ It was a welcome call for global action on factory farming alongside other major issues including climate change and deforestation.

"Deforestation, industrial agriculture, illegal wildlife trade, pollution, climate change, water scarcity, inefficient sanitation and waste management and other types of environmental degradation increase the risk of future pandemics and need to be tackled," said the EU Council's conclusions in the run-up to the UN's Food Systems Summit due to take place the year after. Echoing calls that protecting people means protecting animals too, the Council insisted that policy "must be guided by the 'one health' principle to ensure both human and ecosystem health". ${ }^{31}$

The Covid-19 crisis has "sharpened the focus on the inadequacy of the global response to the climate and biodiversity emergencies," says the Council conclusions. ${ }^{32}$ Factory farming is not only a melting pot for future pandemics, it is also a major driver of wildlife declines. And the burgeoning livestock sector worldwide already contributes 14.5 per cent of greenhouse gas emissions, ${ }^{33}$ which is more than the exhaust fumes from all the world's planes, trains and cars put together. ${ }^{34}$

A key theme in the EU Council document is the need for far-reaching reform of the food system, pledging to support efforts to scale-up action aimed at continuing the "transformation" of the current food system to one more healthy and sustainable.

It marked global entry into a crucial moment in history where the future viability of society could well be defined by its response to the Covid-19 pandemic and the changes made to a global food system which has such a bearing on future sustainability.

In this age of pandemic, climate and biodiversity emergency, there is growing recognition of the need for a wholesale move away from unsustainable industrial farming toward a future-fit food system based on regenerative agriculture. Farming that works in harmony with nature: putting back soil health, bringing pollinators and other wildlife swarming back, conserving water, being kind to animals and protecting the future for all.

Urgent action is needed globally to move away from damaging industrial farming practices in favour of regenerative food; without factory farming and with much less dependence on resource-intensive animal products.

In the words of the United Nations, we need to seize this moment to "build back better". ${ }^{35}$ And to do this, we need to reset the way we view animals and nature.

The crucial thing for genuinely resilient, inclusive sustainability is that farming works in harmony with nature: that it is regenerative. Putting back soil health, bringing pollinators and other biodiversity swarming back, conserving water and protecting the future for all.

I've seen this for myself all around the world.

In South Africa, I've seen an up-and-coming farmer with chickens that follow his cows in a mixed

\footnotetext{
${ }^{30}$ Council of the European Union, Council conclusions on EU priorities at the United Nations and the 75th United Nations General Assembly (September $2020 \quad-$ September 2021) https://data.consilium.europa.eu/doc/document/ST-9401-2020INIT/en/pdf?utm_source=POLITICO.EU\&utm_campaign=8eb450c03e-

EMAIL_CAMPAIGN_2020_07_15_04_59\&utm_medium=email\&utm_term=0_10959edeb5-8eb450c03e-189131121 [13 July 2020]

${ }^{31}$ Ibid.

${ }^{32}$ Ibid.

${ }^{33}$ Food and Agriculture Organisation of the United Nations (FAO), Key Facts and Findings, By the numbers: GHG emissions by livestock

http://www.fao.org/news/story/en/item/197623/icode/\#: :text=Total\%20emissions\%20from\%20global\%20livestock,of\%20all\%20a nthropogenic\%20GHG\%20emissions

${ }^{34}$ International Livestock Research Institute (ILRI), Comparison of greenhouse gas emissions from livestock and transport (19.09.18), https://www.cgiar.org/news-events/news/fao-common-flawed-comparisons-greenhouse-gas-emissions-livestock-transport/

35 United Nations, Covid 19 Response, 2020, Climate Change and COVID-19: UN urges nations to 'recover better' [online] https://www.un.org/en/un-coronavirus-communications-team/un-urges-countries-\%E2\%80\%98build-back-better\%E2\%80\%99
} 
rotation. No need for antibiotics - the animals are naturally healthy. In the US, I know of farmers looking after the soil by keeping it covered all year round, using cover crops, which sheep will then graze in the winter. Avoiding ploughing the soil and thereby disturbing the immense ecosystem in the soil. And in my country, here in the UK, I've seen pigs grazing with cows, both feeding on herb-rich pastures.

In these scenarios, there's no need for lots of chemical fertilisers or pesticides or antibiotics - soils are fertilised naturally, insect and weed pests are kept at bay by the diversity of crops and animals, and everything stays more naturally healthy.

And the great thing about this regenerative, restorative agriculture is that it doesn't need lots of money spent on expensive equipment or chemicals. It's the perfect way for young people to get involved in creating the future of food and farming.

\section{Stark Contrast}

What has been extraordinary about the response to Covid-19 has been how far and fast governments have moved to protect people, introducing life-changing measures across the board in moves normally only associated with wartime.

It shows how quickly changes can be made. In the face of an imminent threat, leaders have stepped up. Society has gone into battle with an invisible enemy.

Yet, the action of governments worldwide on Covid-19 so far stands in stark contrast to efforts on factory farming, climate change and the collapse of nature.

Make no mistake, scientific evidence is clear that the level of threat posed by unsustainable farming practices and climate breakdown could plunge the world into unimaginable crisis. ${ }^{36} 37$

However, few leaders of any persuasion have yet been willing to do what it takes. Few want to take action now, on their watch, to prevent future crises beyond their reign. As one politician said of climate change, 'I know what to do, I just don't know how to get re-elected'. Businesses locked into quarterly or annual returns, obligated to show immediate profit for shareholders, are unwilling to turn their world upside down and risk their business until the world turns upside down too. And so, we are locked into a circle of short-term thinking. Where anything other than incremental change, a minor evolution of the status quo, seems radical and unrealistic.

Yet, the Coronavirus pandemic has shown how fragile society really is; that for the sake of a decent tomorrow, appropriate measures are needed today.

Without urgent action to address the unsustainability of our food system, the climate crisis and the collapse of nature, we could find ourselves again fighting an 'invisible enemy', only this time in a war without end.

Talking at Compassion in World Farming's 'Extinction' conference in 2017, former European Commission director-general for the environment, Karl Falkenberg, pointed out how society rarely makes major changes without a bloody nose. Talking about food, climate and the environment, Falkenberg said, "Why with all the knowledge that we have, why can we still not get the right governance decisions? Why do we continuously do the wrong things that we know are wrong until the next disaster hits us? We do need bloody noses before collectively we start modifying systems". ${ }^{38}$

Whereas, with climate change, there is 'still' a decade or so to solve it so that bloody nose hasn't kicked in yet. The same can be said for the collapse in nature, the decline in pollinating insects, bees and the like. As for the world's oceans, they still have fish in them. Well, for another two to three decades anyway. And saving the world's soils feels like a lifetime away before society hits the buffers. Let alone future pandemics from factory farmed animals in conditions that provide the perfect breeding ground for disease.

As Falkenberg put it, "Collectively, we are living beyond the supporting capability of this blue planet. And we are doing it while we know that this is the only planet we have. It is a fundamental contradiction. It's short termism in the worst form we can imagine."

With Covid-19, the immediacy of the 'attack' from the invisible enemy - mounting death tolls and the

\footnotetext{
${ }^{36}$ ROCKSTRÖM, J. et al., A safe operating space for humanity, Nature , 461 (2009) 472-475

${ }^{37}$ HUGHES, T.P. et al., Multiscale regime shifts and planetary boundaries, Trends in Ecology \& Evolution, July 2013, 28/7 (2013) 388-395

${ }^{38}$ YouTube, Compassion in World Farming Extinction and Livestock Conference, Peace with Nature: the challenge of sustainability (2017) [online]

7iZXkicZxfRMp9U7euR3GvhpZTR1V5y\&index $=23 \& \mathrm{t}=0 \mathrm{~s}$ https://www.youtube.com/watch?v=3ozmwQ2Pr6g\&list=PL-
} 
prospect of many more - required political leaders across the world to do things previously unimaginable for the common good. The effects were immediate and far reaching. It wasn't something politicians could put off for another day.

Perhaps the world's response to Covid-19 will break the mould and establish a new way of looking at threats which are just beyond the immediate horizon. Perhaps, as a global society, we will now find it within ourselves to take the future more seriously. The response to Covid-19 has arguably set the standard for what can be done to stave off other serious threats facing society, including factory farming.

Whilst the origin of the Covid-19 pandemic has been linked to wildlife caught up in wet markets for food, the next one could come from an incarcerated pig or chicken. From animals 'grown' like mere commodities and fed on the fruits of deforestation. Either way, factory farms could be making victims of us all. Never before has there been a more potent example of how the health of animals and people are so closely intertwined.

In the war against invisible enemies, protecting people means protecting animals too.

\section{Conclusion}

Covid-19 offers a potent demonstration of what could happen if we don't heed the warning signs.

It seems clear that a key component of reducing the risk of serious diseases in the future is to reconnect with our humanity for animals and for the environment. To ensure that the sentience of animals - their ability to feel pain, to suffer, and to experience a sense of joy if we let them - whether wild or farmed, lies at the heart of future disease control strategies.

Urgent action is needed globally to move away from industrial farming practices that risk public and animal health and welfare in favour of a regenerative, agroecological food system - in harmony with nature without factory farming and with much less dependence on intensive animal products.

\section{References}

- American Public Health Association APHA Precautionary Moratorium on New and Expanding Concentrated Animal Feeding Operations (Nov 05 2019), Policy Number: 20194, https://www.apha.org/policies-and-advocacy/public-health-policy-statements/policydatabase/2020/01/13/precautionary-moratorium-on-new-and-expanding-concentrated-animalfeeding-operations

- ARIMA, E.Y. et al., Statistical confirmation of indirect land use change in the Brazilian Amazon Environ. Res. Lett. 6 (2011) 024010 [online] https://iopscience.iop.org/article/10.1088/17489326/6/2/024010/pdf

- Avian influenza goes global, but don't blame the birds. Leading Edge (editorial). The Lancet $\begin{array}{lllll}\text { Infectious } & \text { Diseases, } & 6 & \text { (April } & \text { 2006) }\end{array}$ https://www.thelancet.com/journals/laninf/article/PIIS1473-3099(06)70417-0/fulltext

- BAJŽELJ, B. et al., Importance of food-demand management for climate mitigation, Nature Climate Change, 4 (2014) 924-929

- CASSIDY, E.M et al., Redefining agricultural yields: from tonnes to people nourished per hectare. University of Minnesota. Environ. Res. Lett. 8 (2013) 034015 doi:10.1088/1748-9326/8/3/034015

- Centers for Disease Control and Prevention, [online] https://www.cdc.gov/flu/pandemicresources/2009-h1n1-pandemic.html [Last accessed: April 12, 2020]

- Centers for Disease Control and Prevention, Transmission of Avian Influenza A Viruses Between Animals and People, [online] https://www.cdc.gov/flu/avianflu/virus-transmission.htm

- Centers for Disease Control and Prevention, Zoonotic Diseases, [online] https://www.cdc.gov/onehealth/basics/zoonotic-diseases.html

- Chief Investment Officer, Chinese Virus Could Be a 'Black Swan Like No Other': Moody's (2020) [online] https://www.ai-cio.com/news/chinese-virus-black-swan-like-no-moodys-says/

- Council of the European Union, Council conclusions on EU priorities at the United Nations and the 75th United Nations General Assembly (September 2020 - September 2021) https://data.consilium.europa.eu/doc/document/ST-9401-2020-

INIT/en/pdf?utm_source=POLITICO.EU\&utm_campaign=8eb450c03e-

EMAIL_CAMPAIGN_2020_07_15_04_59\&utm_medium=email\&utm_term=0_10959edeb58eb450c03e-189131121 [13 July 2020] 
- DHINGRA, M.S. et al., Geographical and Historical Patterns in the Emergences of Novel Highly Pathogenic Avian Influenza (HPAI) H5 and H7 Viruses in Poultry, Frontiers in Veterinary Science, 5 (2018) 84, doi: 10.3389/fvets.2018.00084

- Editorial, The risk of an influenza pandemic is fact, not fiction, New Scientist (24 September 2011) 3 https://www.newscientist.com/article/mg21128313-300-the-risk-of-an-influenza-pandemic-isfact-not-

fiction/\#: :text=Work\%20reported $\% 201$ ast $\% 20$ week $\% 20$ suggests,flu $\% 20 \mathrm{a} \% 201$ ethal $\% 20$ pandemi $\mathrm{c} \% \mathrm{E} 2 \% 80 \% 9 \mathrm{D}$

- FRAANJE, W., GARNETT, T. Soy: food, feed, and land use change. (Foodsource: Building Blocks). Food Climate Research Network, University of Oxford (2020)

- Food and Agriculture Organisation of the United Nations (FAO), Key Facts and Findings, By the numbers: GHG emissions by livestock [online] http://www.fao.org/news/story/en/item/197623/icode/\#: :text=Total\%20emissions\%20from\%20gl obal\%20livestock,of\%20all\%20anthropogenic\%20GHG\%20emissions

- GREGER, M., The Human/Animal Interface: Emergence and Resurgence of Zoonotic Infectious Diseases, Critical Reviews in Microbiology, 33 (2007) 243-299

- GIBBS, J.A., ARMSTRONG, J.S., DOWNIE, J.C., From where did the 2009 'swine-origin' influenza A virus (H1N1) emerge? Virology Journal, $6 \quad$ (2009) 207 http://www.virologyj.com/content/6/1/207

- GIBB, R. et al., Zoonotic host diversity increases in human-dominated ecosystems, Nature , 584 (2020) 398-402

- HUGHES, T.P. et al., Multiscale regime shifts and planetary boundaries, Trends in Ecology \& Evolution, July 2013, 28/7 (2013) 388-395

- International Livestock Research Institute (ILRI), Comparison of greenhouse gas emissions from livestock and transport (19.09.18), https://www.cgiar.org/news-events/news/fao-common-flawedcomparisons-greenhouse-gas-emissions-livestock-transport/

- LYMBERY, P., Dead Zone: Where the Wild Things Were (London 2017)

- MACKENZIE, D., Five easy mutations to make bird flu a lethal pandemic, New Scientist (24 September 2011) 14 (online article 21 September)

- MOTTET, A., et al., Livestock: On our plates or eating at our table? A new analysis of the feed/food debate. Global Food Security, 14 (2017) 1-8. https://www.sciencedirect.com/science/article/abs/pii/S2211912416300013

- OTTE, J. et al. Industrial Livestock Production and Global Health Risks. Pro-Poor Livestock Initiative (June 2007) www.fao.org/ag/AGAinfo/projects/en/pplpi/docarc/rephpai_industrialisationrisks.pdf

- POORE, J., NEMECECK, T., Reducing food's environmental impacts through producers and consumers, Science 360 (2018) 987-992

- RAUSCH, L.L. et al., Soy expansion in Brazil's Cerrado, Conservation Letters, 12 (2019) e12671.

- https://doi.org/10.1111/conl.12671

- RITCHIE, H., ROSER, M., Our World in Data, Global land use for food production (2019) https://ourworldindata.org/land-use (accessed November 2020)

- ROCKSTRÖM, J. et al., A safe operating space for humanity, Nature , 461 (2009) 472-475

- The New York Times, We Made the Coronavirus Epidemic (2020) [online] https://www.nytimes.com/2020/01/28/opinion/coronavirus-china.html

- Total world cropland area from FAOSTAT: land use in 2018 (FAOSTAT, Inputs: Land use, http://www.fao.org/faostat/en/\#data/RL

- United Nations, Covid 19 Response, 2020, Climate Change and COVID-19: UN urges nations to 'recover better' [online] https://www.un.org/en/un-coronavirus-communications-team/un-urgescountries- $\%$ E2\%80\%98build-back-better $\%$ E2\%80\%99

- WEBSTER, R.G., Wet markets - a continuing source of severe acute respiratory syndrome and influenza? Lancet, 363 (2004) 234-36

- WAlZER, C., COVID-19 and the Curse of Piecemeal Perspectives. Front. Vet. Sci. 7 (2020) 582983. https://www.frontiersin.org/articles/10.3389/fvets.2020.582983/full

- World Health Organisation (WHO), Cumulative Number of Confirmed Human Cases of Avian Influenza $\mathrm{A} /(\mathrm{H} 5 \mathrm{~N} 1)$ [online] http://www.who.int/csr/disease/avian_influenza/country/cases_table_2011_08_09/en/index.html [Reported to WHO, 9 August 2011] 
- World Health Organisation (WHO), 2009 H1N1 Pandemic (H1N1pdm09 virus) [online] http://www.searo.who.int/linkfiles/news_letters_nov2010.pdf

- YouTube, Compassion in World Farming Extinction and Livestock Conference, Peace with Nature: the challenge of sustainability (2017) [online] https://www.youtube.com/watch?v=3ozmwQ2Pr6g\&list=PL7iZXkicZxfRMp9U7euR3GvhpZTR1V5y\&index $=23 \& \mathrm{t}=0 \mathrm{~s}$ 